УДК 577.391:576.312.33

T.A. REDCHUK ${ }^{1}$, A.I. ROZHOK ${ }^{2}$, O.W. ZHUK ${ }^{2}$, I.A. KOZERETSKA ${ }^{2}$, T.A. MOUSSEAU ${ }^{3}$

${ }^{1}$ O.V. Palladin Institute of Biochemistry of NAS of Ukraine, Kyiv ${ }^{2}$ Taras Shevchenko National University of Kyiv E-mail: arozhok@gmail.com

${ }^{3}$ University of South Carolina, Columbia, USA

\section{DNA METHYLATION IN DROSOPHILA MELANOGASTER MAY DEPEND ON LINEAGE HETEROGENEITY}

DNA methylation has been discovered in Drosophila only recently. Current evidence indicates that de novo methylation patterns in drosophila are maintained in a different way compared to vertebrates and plants. As the genomic role and determinants of DNA methylation are poorly understood in invertebrates, its link with several factors has been suggested. In this study, we tested for the putative link between DNA methylation patterns in Drosophila melanogaster and radiation or the activity of $P$ transposon. Neither of the links was apparent from the results, however, we obtained some hints on a possible link between DNA methylation pattern and genomic heterogeneity of fly lineages.

(C) T.A. REDCHUK, A.I. ROZHOK, O.W. ZHUK,

I.A. KOZERETSKA, T.A. MOUSSEAU, 2012
Introduction. DNA methylation is believed to play a crucial role in regulation of many genomic processes in eukaryotes, including gene silencing [1, 2], chromatin structuring [3], and repression of the activity of transposons $[4,5]$. In most cases and groups of organisms, methylation involves addition of the methyl group to the $5^{\text {th }}$ carbon atom in the cytosine molecule leading to creation of the 5-methylcytosine. The genome-wide pattern is heritable and copied to new DNA molecules during replication (maintenance methylation) or reproduced anew during ontogenesis (de novo methylation) [6]. Most methylation in vertebrates and plants involves cytosines within $\mathrm{CpG}$ dinucleotide motifs. Unlike vertebrates, little is known about methylation and its functions in invertebrates, particularly in Drosophila. However, there are a number of features that distinguish Drosophila from other organisms for which methylation is known, which makes the fly a rather interesting study object in the context of methylation. First of all, in Drosophila both types of methylation - maintenace and de novoappear to be catalyzed by the DNA methyltransferase 2 , which differs from the mechanism in vertebrates where these functions are performed by DNA methyltranferases 1 and 3A/B, respectively [7, 8]. Second, methylation in Drosophila is not so heavily concentrated on cytosine in $\mathrm{CpG}$ dinucleotide contexts as in vertebrates and plants, and methylation in $\mathrm{CpT}$, $\mathrm{CpC}$ and $\mathrm{CpA}$ motifs is very common $[7,9]$. And third, unlike in vertebrates, the amount of DNA methylation rapidly decreases during ontogenesis, with only about $1 \%$ of cytosines remaining methylated in adults $[9,10]$.

Although one of the earliest publications indicating the presence of methylation in Drosophila dates back to the 1980s [11], methylation has long been thought to be restricted to polytene chromosomes. Just a decade ago, methylation was still thought to be absent from the Drosophila genome [12, 13], but was discovered soon thereafter $[9,14,15]$.

One of the most interesting peculiar traits in Drosophila is the fact that its DNA methylation is scattered throughout coding regions of genes, again unlike in vertebrates which methylation 
is primarily concentrated in the gene CG-rich promoter regions [16]. This difference may be indicative of a potential difference in prevalent functions: gene silencing in vertebrates and gene expression regulation in Drosophila (see also [17]).

DNA methylation has been shown to be involved in retrotransposon repression [18, 19]. In this context, an interesting question that still remains open is whether DNA methylation is involved in repression of transposon activity in Drosophila. Transposons do get methylated [20]. However, there is evidence that appears to argue against the involvement of methylation in transposon activity regulation in Drosophila (reviewed in [16]), and most of the regulative function is ascribed to RNA interference. Nonetheless, experiments with transgenic hypermethylated flies [21] demonstrate that hypermethylation leads to extra methylation of heterochromatin and, thus, has a profound effect on its structure. As the majority of transposable elements are actually found in heterochromatin [22], such an influence of methylation may be expected to cause steric silencing of many heterochromatin structures, including transposons. In the case of $\mathrm{P}$ elements, two primary repression mechanisms are known - repression proteins produced by incomplete copies of P element and RNA interference. However, methylation may well constitute at least part of the repression system acting through chromatin restructuring or other as yet unidentified mechanisms.

The aim of the present study was to address this question using flies with potentially differing levels of transposon activity. Experimental evidence suggests that ionizing radiation causes increased activity of transposition in Drosophila transposable element $[23,24]$. In this study, we hypothesized that the putative involvement of DNA methylation in Drosophila in regulation of transposon activity should produce different genome-wide methylation patterns in flies from radioactively uncontaminated areas and flies living near a cooling pond from the Chornobyl Nuclear Power Plant, an area with very high ambient radiation levels. Other research that is underway in our lab suggests rapid evolutionary responses to $\mathrm{P}$ element invasion in populations from highly contaminated areas that may be related to maternally inherited cytotype (unpublished data). These data are in accordance with the hypothesis of higher activity of $\mathrm{P}$ elements in radioactively contaminated areas, as the rate of evolution of cytotype is inherently assumed to depend on the activity of $\mathrm{P}$ elements. In this way, if the hypothesis of the involvement of methylation in $\mathrm{P}$ element regulation turns to be true, we can expect higher methylation levels in populations with cytotypes that are characterized with a more developed $\mathrm{P}$ element repression potential (i.e. $\mathrm{Q}$ and $\mathrm{P}$ cytotypes). In the case of Ukrainian populations, this means that the genome of Chorobyl flies is expected to be methylated heavier than that of any other population from uncontaminated areas. Going further, evidence of the involvement of DNA methylation in $P$ element activity regulation would imply that DNA methylation is actually part of the cytotype «hardware», along with suppressor proteins and RNA interference.

Materials and methods. D. melanogaster flies were collected in the summer 2009 from three locations in Ukraine. The first location («Cooling Pond») was located adjacent to the Chornobyl Nuclear Power Plant cooling pond and had an ambient background radiation level of about $2100 \mu \mathrm{R} / \mathrm{h}$. The second site («Varva») was located in Chernigiv region of Ukraine, an area which was not affected by the fallout from the Chornobyl disaster, and has very low natural background radiation levels (typically $<3 \mu \mathrm{R} / \mathrm{h}$ ), making it one of the cleanest places in Ukraine in this respect. The third population (Motovylivka) was sampled $50 \mathrm{~km}$ south of Kyiv from a non-contaminated area. All the three populations are known to contain fragments of $\mathrm{P}$ elements and these $\mathrm{P}$ elements have two HhaI restriction sites [25]. Laboratory wild type strains Canton-S, which does not contain $\mathrm{P}$ elements and possesses $\mathrm{M}$ cytotype, and Harwich, which contains $\mathrm{P}$ element and has well-developed $\mathrm{P}$ cytotype were used in 
standard crosses to obtain control progeny with activated or repressed $\mathrm{P}$ element.

DNA was extracted using the DNeasy Blood \& Tissue DNA Extraction Kit («Qiagen», USA) following manufacturer's protocol. A total of 50 flies were used in each extraction.

To assess the patterns of methylation, the restriction endonuclease-based technique referred to as MSRE (Methylation Sensitive Restriction Enzyme analysis) was used (for summary see [26]). DNA was digested with the cytosine methylation-sensitive HhaI restriction endonuclease which restriction site includes CpG doublets. 10U HhaI were used with the appropriate buffer in a total restriction mix volume of $35 \mu$. Incubation lasted for 5 hours at $37^{\circ} \mathrm{C}$.

Digestion results were visualized using the standard $1 \%$ agarose gel electrophoresis with ethidium bromide staining.

Results and discussion. To test whether radiation affects DNA methylation pattern in D. melanogaster we analysed MSRE patterns of female and male flies caught in the wild. The results are shown in Fig. 1. As can be seen from Fig. 1, a clearly discernible difference in MSRE methylation patterns exists between males and females from two populations - Varva and Cooling Pond. This difference is, however, absent from Motovylivka flies, which DNA seems to be less methylated. No radiation level-consistent pattern is evident from Fig. 1, as the two populations from clean areas produced different MSRE pattters. Besides, the sex dimorphism shared by the Cooling Pond and Motovylivka flies contributes to this conclusion.

To analyze the putative link between DNA methylation and the activity of transposons, we tested laboratory wild type strains Canton-S (lacks P element at all), Harwich (possesses autonomous $\mathrm{P}$ element which is repressed though by the P cytotype), as well as their crosses female Canton- $S \times$ male Harwich (which results in the activation of $\mathrm{P}$ element in the genome of the F1 progeny) and female Harwich $\times$ male Canton $-S$ (the F1 progeny contain

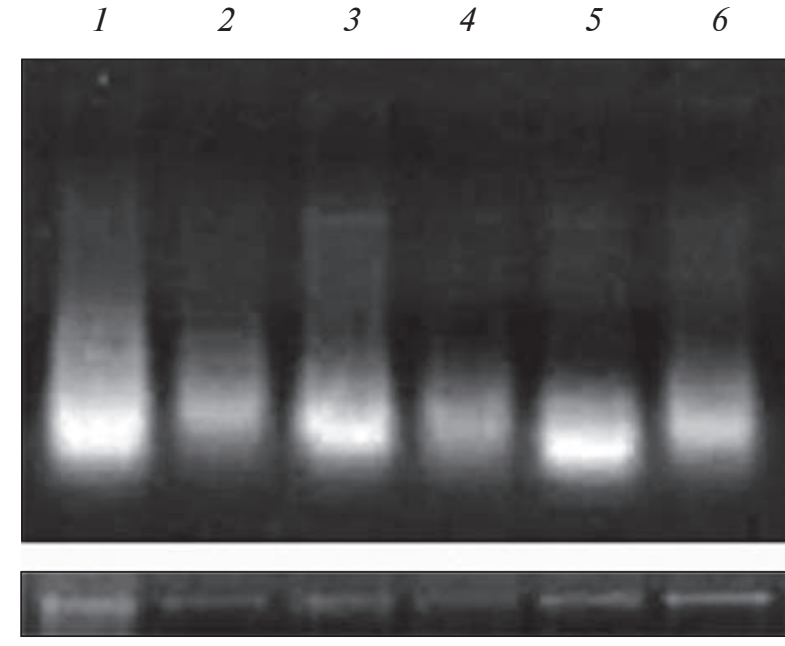

Fig. 1. MSRE patterns of DNA methylation in wild caught $D$. melanogaster flies: 1 - Varva females; 2 - Varva males; 3 - Cooling Pond females; 4-Cooling Pond males; 5 - Motovylivka females; 6 - Motovylivka males

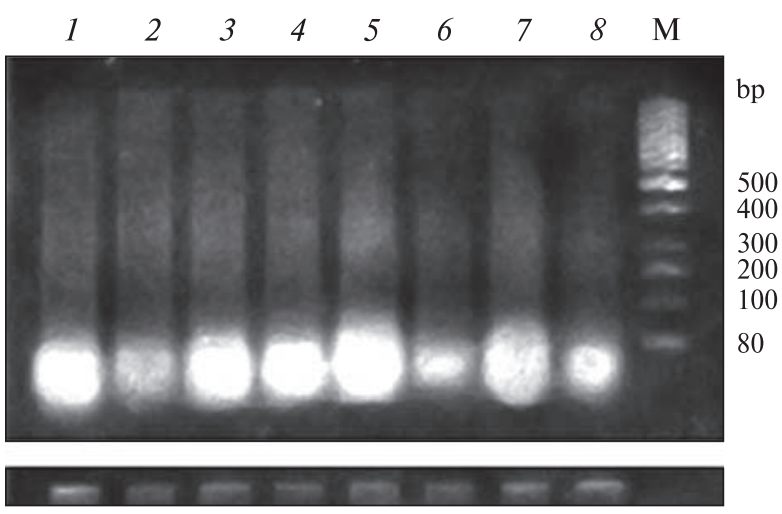

Fig. 2. MSRE patterns of DNA methylation in laboratory strains and their hybrids: $1-$ females Harwich $\times$ $\times$ Canton $-S$, 2- males Harwich $\times$ Canton $-S, 3-$ females Canton- $S \times$ Harwich, $4-$ males Canton $-S \times$ Harwich, 5females Canton-S, 6 - males Canton-S, $7-$ females Harwich, $8-$ males Harwich, M - molecular weight marker

$\mathrm{P}$ element which activity is repressed). The respective MSRE patterns are shown in Fig. 2. As can be seen from Fig. 2, hybrids of both sexes produce more event MSRE patterms, and sex dimorphism is more notable from pure strains. This distribution suggests that activation of $\mathrm{P}$ element is not linked with altered methylation, as both crosses produced similar 
MSRE patterns. However, interestingly both laboratory strains share a similar pattern that is still different from that produced by hybrids.

The results we obtained suggest that neither the activity of transposons nor radiation exposure correlate with MSRE methylation patterns in D. melanogaster. However, we obtained very similar methylation patterns in two very different laboratory strains. As both strains are very old, they are highly inbred. We suggest that inbreeding leading to significantly reduced genetic heterogeneity may have accounted for the methylation patterns we obtained. This hypothesis needs further testing and suggests that genome heterogeneity may influence the pattern of de novo methylation in Drosophila.

Authors thank Dr. G. Milinevskyi, the staff of Biology Department of Mechnikov National University of Odesa, and the staff of the National Institute of Viniculture and Wine Industry UAAS for their valuable help in material collection.

\section{Т.А. Редчук, А.И. Рожок, О.В. Жук, И.А. Козерецкая, Т.А. Мюссе ВОЗМОЖНАЯ СВЯЗЬ МЕЖДУ МЕТИЛИРОВАНИЕМ ДНК \\ И ГЕТЕРОГЕННОСТЬЮ ПОПУЛЯЦИЙ У DROSOPHILA MELANOGASTER}

Метилирование ДНК описано у дрозофилы сравнительно недавно. Современные данные свидетельствуют о том, что механизмы метилирования de novo у дрозофилы отличаются от таковых у позвоночных животных и растений. Поскольку на сегодня роль метилирования у беспозвоночных окончательно не выяснена, этот процесс связывают с несколькими факторами. В настоящем исследовании проверена потенциальная связь между метилированием ДНК у дрозофилы, радиоактивным загрязнением и активностью $P$ транспозона. Наличие такой связи не подтверждено полученными результатами. В то же время получены свидетельства возможной связи метилирования ДНК с гетерогенностью популяций.

$$
\begin{gathered}
\text { T.А. Редчук, А.І. Рожок, О.В. Жук, } \\
\text { І.А. Козерецька, Т.А. Мюссе }
\end{gathered}
$$

\section{МОЖЛИВИЙ ЗВ'ЯЗОК МІЖ МЕТИЛУВАННЯМ ДНК ТА ГЕТЕРОГЕННІСТЮ ПОПУЛЯЦІЙ У DROSOPHILA MELANOGASTER}

Метилування ДНК було описано у дрозофіли досить недавно. Сучасні дані свідчать про те, що механізми метилування de novo у дрозофіли відріз- няються від таких у хребетних тварин та рослин. Оскільки зараз роль метилування у безхребетних остаточно не з'ясована, цей процес пов'язують 3 кількома факторами. В даному дослідженні перевірено потенційний зв'язок між метилуванням ДНК у дрозофіли, радіоактивним забрудненням та активністю $Р$ транспозона. Наявність такого зв'язку не підтверджено одержаними результатами. Натомість отримано дані, що свідчать про можливий зв'язок метилування ДНК з гетерогенністю популяцій.

\section{REFERENCES}

1. Attwood J.T., Yung R.L., Richardson B.C. DNA methylation and the regulation of gene trans cription // Cell. Mol. Life Sci. - 2002. - 59. - P. 241257.

2. Bird A. DNA methylation patterns and epigenetic memory // Genes Dev. - 2002. - 16. - P. 6-21.

3. Robertson K.D. DNA methylation and chromatin unraveling the tangled web // Oncogene. - 2002. 21. - P. 5361-5379.

4. Yoder J.A., Walsh C.P., Bestor T.H. Cytosine methylation and the ecology of intragenomic parasites // Trends Genet. - 1997. - 13. - P. 335-340.

5. Walsh C.P., Chaillet J.R., Bestor T.H. Transcription of IAP endogenous retroviruses is constrained by cytosine methylation // Nat. Genet. - 1998. - 20. P. 116-117.

6. Colot V., Rossignol J.-L. Eukaryotic DNA methylation as an evolutionary device // BioEssays. 1999. - 21. - P. 402-411.

7. Kunert N., Marhold J., Stanke J., Stach D., Lyko F. A Dnmt2-like protein mediates DNA methylation in Drosophila // Development. - 2003. - 130. P. 5083-5090.

8. Narsa Reddy M., Tang L.Y., Lee T.L., James Shen C.K. A candidate gene for Drosophila genome methylation // Oncogene. - 2003. - 22. - P. 6301-6303.

9. Lyko F., Ramsahoye B.H., Jaenisch R. DNA methylation in Drosophila melanogaster // Nature. 2000. - 408. - P. 538-540.

10. Field L.M., Lyko F., Mandrioli M., Prantera G. DNA methylation in insects // Insect Mol. Biol. 2004. - 13. - P. 109-115.

11. Eastman E.M., Goodman R.M., Erlanger B.F., Miller O.J. 5-methylcytosine in the DNA of the polytene chromosomes of the Diptera Sciara coprophila, Drosophila melanogaster and D. persimilis // Chromosoma. - 1980. - 79. - P. 225239.

12. Regev A., Lamb M.J., Jablonka E. The role of DNA methylation in invertebrates: developmental regulation or genome defense? // Mol. Biol. Evol. 1998. - 15. - P. 880-891.

13. Lyko F., Whittaker A.J., Orr-Weaver T.L., Jaenisch R. 
The putative Drosophila methyltransferase gene dDnmt2 is contained in a transposon-like element and is expressed specifically in ovaries // Mech. Develop. - 2000. - 95. - P. 215-217.

14. Tweedie S., Ng H.-H., Barlow A.L., Turner B.M., Hendrich B., Bird A. Vestiges of a DNA methylation system in Drosophila melanogaster? // Nat. Genet. -1999. - 23. - P. 389-390.

15. Gowher H., Leismann O., Jeltsch A. DNA of Drosophila melanogaster contains 5-methylcytosine // EMBO J. - 2000. - 19. - P. 6918-6923.

16. Mandrioli M., Borsatti F. DNA methylation of fly genes and transposons // Cell Mol. Life Sci. 2006. - 63. - P. 1933-1936.

17. Simmen M.W., Leitgeb S., Charlton J., Jones S.J., Harris B.R., Clarck V.H., Bird A. Nonmethylated transposable elements and methylated genes in a chordate genome // Science. - 1999. - 283. P. 1164-1167.

18. Phalke S., Nickel O., Walluscheck D., Hortig $F$., Onorati M.C., Reuter G. Retrotransposon silencing and telomere integrity of somatic cells of Drosophila depends on the cytosine-5methyltransferase Dnmt2 // Nat. Genet. - 2009. 41. - P. 696-702.

19. Schaeffer M., Lyko $F$. Lack of evidence for DNA methylation of Invader4 retroelements in Drosophila and implications for Dnmt2-mediated epigenetic regulation // Nat. Genet. -2010. -42. P. 920-921.

20. Salzberg A., Fisher O., Siman-Tov R., Ankri S. Identification of methylated sequences in genomic DNA of adult Drosophila melanogaster // Biochem.
Biophys. Res. Communs. - 2004. - 322. - P. 465469.

21. Weissmann F., Muyrers-Chen I., Musch T., Stach D., Weissler M., Paro R., Lyko F. DNA hypermethylation in Drosophila melanogaster causes irregular chromosome condensation and dysregulation of epigenetic histone modifictions // Mol. Cell. Biol. - 2003. - 23. - P. 2577-2586.

22. Kaminker J.S., Bergman C.M., Kronmiller B., Carlson J., Svirskas R., Patel S., Frise E., Wheeler D.A., Lewis S.E., Rubin G.M., Ashburner M., Celniker S.E. The transposable elements of the Drosophila melanogaster euchromatin: a genomics perspective // Genome Biol. - 2002. - 3, № 12.

23. Handler A.M., Gomez S.P. P element excision in Drosophila is stimulated by gamma-irradiation in transient embryonic assays // Genet. Res. - 1997. 70. - P. 75-78.

24. Valilyeva L.A., Vikhristyuk O.V., Antonenko O.V., Zakharov I.K. Induction of mobile genetic elements transposition in Drosophila melanogaster genome by different stress factors // Vestnik VOGiS (VOGiS Herald). - 2007. - 11. - P. 662670.

25. Rozhok A.I., Bilousov O.O., Protsenko O.V., Zhuk O.V., Kozeretska I.A. Occurrence of $\mathrm{P}$ element in natural populations of Drosophila melanogaster in Ukraine // Dros. Inf. Serv. - 2009. - 92. - P. 7378.

26. Dahl C., Guldberg P. DNA methylation analysis techniques // Biogerontology. - 2003. -4. - P. 233250 .

Received 28.01.11 